\title{
Antioxidant Activity of Blackthorn (Prunus spinosa L.) Fruit Extract and Cytotoxic Effects on Various Cancer Cell Lines
}

\author{
Prunus spinosa L. Ekstresinin Çeşitli Kanser Hücre Soylarındaki \\ Antioksidan ve Sitotoksik Etkileri
}

\author{
Nihal KARAKAS $\odot$, Mehmet Evren OKUR $\odot$, Irem OZTURK $\odot$, Sule AYLA $\odot$, Ayse Esra KARADAG $\odot$, \\ Derya Çiçek POLAT ๑
}

Ethics Committee Approval: Not Applicable.

Conflict of interest: The authors declare that they have no conflict of interest.

Funding: None.

Informed Consent: Not Applicable.
Cite as: Karakas N, Okur ME, Ozturk I, Ayla S, Karadag AE, Polat DC. Antioxidant activity of Blackthorn (Prunus spinosa L.) fruit extract and cytotoxic effects on various cancer cell lines. Medeniyet Med J. 2019;34:297-304.

\begin{abstract}
Objective: Blackthorn (Prunus spinosa $L$. (Rosaceae) is a shrup whose fruits are consumed as food in Turkey. This study was aimed to evaluate antioxidant activity of methanol extract of $P$. spinosa and its cytotoxic effects on cancer cell lines.

Method: Methanol extract of $P$. spinosa fruit was evaluated for its in vitro cytotoxic activity on multiform (GBM) brain cancer (LN229, U87 and T98G) and pancreas cancer (PANC-1 and AsPC-1) cell lines. Cell viability assays were performed by calculating the percentage of viable cells using a luminescence system, and spectrophotometrically. measuring its antioxidant ABTS and DPPH radical scavenging activities. Differences were considered as statistically significant at $p^{*}<0.001$ and $p^{* *}<0.0005$ according to unpaired student $t$-test.

Results: Methanol extract of $P$. spinosa fruit showed $2548 \pm 18 \mathrm{mg} G A E / 100 \mathrm{~g}$ corresponding to the total phenolic content, and moderate antioxidant activity $(0.1896 \pm 0.1143$ and $0.0729 \pm 0.0348$ ) by ABTS and DPPH• assays.

Conclusion: To the best of our knowledge, after evaluating the results of brain and pancreas cancer cell lines, significant cytotoxic activities with 50-63\% cell viability of GBM brain cancer cells were determined while no cytotoxicity was observed on pancreas cancer cell lines, PANC-1; and AsPC-1. The results of this study showed that the methanol extract of $P$. spinosa fruit has significant antioxidant capacity and leads to statistically significant decreased viability on glioblastoma brain cancer cells.
\end{abstract}

Keywords: Prunus spinosa, blackthorn, cytotoxicity, cancer, antioxidant activity

Öz

Amaç: Çakal eriği (Prunus spinosa L.), Gülgiller (Rosaceae) familyasından bir ağaççı türüdür ve Türkiye'de meyvesi besin olarak tüketilmektedir. Bu calıșma P. spinosa metanol ekstresinin antioksidan aktivitesini ve kanser hücre hatları üzerindeki sitotoksik etkilerini değerlendirmeyi amaçlamıştır.

Yöntem: P. spinosa meyvesi metanol ekstresi, glioblastoma multiform (GBM) beyin kanseri (LN229, U-87 ve T98G) ve pankreas kanseri (PANC-1 ve AsPC-1) hücre hatları kullanılarak in vitro sitotoksik aktivitesi araștırılmıștır. Hücre canlıı̆̆ı deneyleri, biyolüminesans sistemi kullanılarak canlı hücrelerin yüzdesinin ve antioksidan aktivitelerinin, spektrofotometrik olarak ABTS ve DPPH radikalleri ile ölçülmesi yoluyla gerçekleştirilmiştir. İstatiksel anlamlılık eşleştirilmemiş öğrenci $t$ testi ile $p^{*}<0.001$ ve $p^{* *}<0.0005$ olarak belirlenmiștir.

Bulgular: P. spinosa meyve metanol ekstresi, ABTS•ve DPPH・ testlerinde toplam fenolik içeriğe karşılık gelen $2548 \pm 18 \mathrm{mg} G A E / 100 \mathrm{~g}$ ve orta düzeyde antioksidan aktivite $(0,1896 \pm 0,1143$ ve $0,0729 \pm 0,0348$ ) göstermiştir.

Sonuc: Elde ettiğimiz bilgiler ıșığında, beyin ve pankreas kanseri hücre hatlarındaki sonuçlarının değerlendirilmesinden sonra, GBM beyin kanseri hücrelerinde \%50-63 arasındaki hücre canlılığı ile önemli derecede sitotoksik aktivitesi belirlenmiş ancak PANC-1 ve AsPC-1 pankreas kanseri hücre hatlarında sitotoksisite gözlenmemiștir. Sonuç olarak, P. spinosa meyvesi metanol ekstresinin önemli antioksidan kapasiteye sahip olduğu ve glioblastoma beyin kanseri hücrelerinin canlılığında istatistiksel olarak anlamlı bir azalmaya yol açtığı gösterilmiştir.

Anahtar kelimeler: Prunus Spinosa, Çakal eriği, sitotoksisite, kanser, antioksidan aktivite
Received: 30 April 2019

Accepted: 17 July 2019

Online First: 27 September 2019

Corresponding Author:

N. Karakas

ORCID: 0000-0002-9096-1512

Istanbul Medipol University, School of Medicine, Departments of Medical Biology, Istanbul Turkey and Istanbul Medipol University, Regenerative and Restorative Medicine Research Center, Istanbul, Turkey nkarakas@medipol.edu.tr

S. Ayla

ORCID: 0000-0003-2143-5268 Istanbul Medipol University, Regenerative and Restorative Medicine Research Center and Department of Histology and Embryology, Istanbul, Turkey

I. Ozturk

ORCID: 0000-0003-3552-1554 Istanbul Medipol University, Regenerative and Restorative Medicine

Research Center, Istanbul, Turkey

M.E. Okur

ORCID: 0000-0001-7706-6452 University of Health Sciences, Faculty of Pharmacy, Department of Pharmacology, Istanbul, Turkey

A.E. Karadag

ORCID: 0000-0002-3412-0807 Istanbul Medipol University, School of Pharmacy, Department of Pharmacognosy, Istanbul, Turkey and Anadolu University, Graduate School of

Health Sciences, Eskisehir, Turkey

D.C. Polat

ORCID: 0000-0002-4331-6828 Ankara University, Faculty of Pharmacy, Department of Pharmaceutical Botanic, Ankara, Turkey

(c) Copyright Istanbul Medeniyet University Faculty of Medicine. This journal is published by Logos Medical Publishing. Licenced by Creative Commons Attribution-NonCommercial 4.0 International (CC BY-NC 4.0) 


\section{INTRODUCTION}

Prunus spinosa $L$. known as "blackthorn" is called as "çakal eriği" in Turkish. $P$. spinosa is a member of Rosaceae family and naturally found in Europe, northwest Africa and West Asia where it is used therapeutically for many years ${ }^{1,2}$. In Turkey, $P$. spinosa leaves are used for constipation, flowers are diuretic and vermicide, and fruits are being used as laxatives for a long time. Also in some regions fruits are also consumed as a compote because of it increases resistance of body, provides blood-building effect and relieves rheumatic pain $^{1,3}$. P. spinosa is a perennial plant and a spiky dwarf tree that can reach a up to 3 or 4 meters, blooming in April-May. Its fruits are bluish black coloured, spherical shaped and sour taste, which ripens towards autumn or winter ${ }^{4}$. It is known that there is a high rate of tannin in $P$. spinosa and it has aromatic and therapeutic properties ${ }^{5}$.

Different parts of $P$. spinosa have been used for treatment, and fruits of $P$. spinosa showed functional therapeutic properties ${ }^{2,6}$. Its fruit juices are used as mouthwash for mucosal lesions of mouth and pharynx due to its anti-inflammatory effect. It was also found that the syrups obtained from the fruits were purgative, and diuretic ${ }^{1} . P$. spinosa is used traditionally in the treatment of hypertension, diabetes and gastrointestinal disorders, as diuretic, in the regulation of menstruation, and making yoghurt ${ }^{7,8}$. It is rich in phenolics and antioxidants ${ }^{2,9,10}$. The fruits of $P$. spinosa contain many bioactive compounds such as tocopherols ( $\alpha$-tocopherol, $\beta$-tocopherol, -tocopherol, $\delta$-tocopherol), ascorbic acid and $\beta$-carotene, anthocyanins (cyanidin-3-routine, peonidine-3-routine, cyanidin-3-glycoside) as well as polyphenolic compounds and flavonoids (routine, quercetin, hyperosit) ${ }^{1,2,11}$. The major bioactive components are coumarin derivatives as aesculetin, umbelliferon and scopoletin; flavonoid derivatives as quercetin and kaempferol ${ }^{6,12}$. Due to these important bioactive components, it has cardiovascular protective, antibacterial and antioxidant effects.
Antioxidant activities of $P$. spinosa fruits have been shown in several studies ${ }^{1,2,12,13}$. Wound healing properties and cytotoxic activity of $P$. spinosa on some cell lines were also investigated in previous studies ${ }^{1,14}$.

In the present study, total phenolic content (TPC) of methanol extract of $P$. spinosa fruit has been determined and investigated in respect to their in vitro antioxidant and cytotoxic activities. The flavonoid compositions of the extracts were revealed by LC-MS. To analyse cytotoxicity, cell viability was measured on various cancer cell lines treated with different doses $(1-20 \mathrm{mg} / \mathrm{ml})$ of methanol extract of $P$. spinosa fruit According to cell viability assays, significant cytotoxic effects of methanol extract of $P$. spinosa fruit was determined in glioblastoma brain cancer cell lines while no toxicity was recorded in pancreatic cancer cells.

\section{MATERIALS and METHODS}

\section{Materials}

The standard chemicals were purchased from Sigma Chemical Co. (St. Louis, MO, USA) and the HPLC-grade solvents from Merck. Methanol was purchased from Sigma-Aldrich, Germany. All other reagents and solvents used were of analytical grade.

\section{Preparation of samples}

Fruits of $P$. spinosa, collected from AhlatlıbelIncek (Date: 15 October 2016), were pureed. The pureed sample was extracted with methanol using a magnetic stirrer (Heidolph MR3001, Sigma-Aldrich). After being filtered, the extracts were concentrated in vacuum at $40^{\circ} \mathrm{C}$ (Heidolph WB2000).

\section{Total phenolic contents of the extract}

Folin-Ciocalteu method was used to determine total phenolic contents of the fruit extract. The mixture was prepared with fruit extract $(5 \mathrm{~mL})$, Folin-Ciocalteu reagent $(0.25 \mathrm{~mL})$ and $\mathrm{Na}_{2} \mathrm{CO}_{3}$ 
$(0.2 \mathrm{~mL})$ and allowed to stand for $15 \mathrm{~min}$ at 45 ${ }^{\circ} \mathrm{C}$. Absorbance of samples was read at $765 \mathrm{~nm}$. A calibration curve $\left(R^{2}=0,9999\right)$ was used for calculating the total phenolic content (TPC) of the extract $^{15}$ and the result was expressed as $\mathrm{mg}$ gallic acid equivalent (gae)/100 $\mathrm{g}$ extract $^{16}$.

\section{In vitro antioxidant assays DPPH・ scavenging assay}

To determine the $P$. spinosa fruit extract antioxidant ability, the DPPH (2,2-diphenyl-1-picrylhydrazyl) radicals were utilized according to the spectrophotometric protocol ${ }^{17}$. Equal volume of $100 \mu M$ DPPH in methanol was added to different concentrations of the extract. The absorbance was read at $517 \mathrm{~nm}$ using a spectrophotometer. The radical scavenging activity was calculated according to the following equation:

DPPH. RSA \% = [(Absorbance ${ }_{\text {control }}$ - Absorbance test sample)/Absorbance $\left.\left.{ }_{\text {control }}\right)\right] \times 100$

All experiments were done in triplicate. BHT was served as the positive control. $\mathrm{IC}_{50}$ rates were detected from a calibration curve ${ }^{15}$.

\section{ABTS. scavenging assay}

2,2'-azino-bis 3-ethylbenzthiazoline-6-sulfonic acid (ABTS) radical scavenging activity of $P$. spinosa fruit extract was determined according to Re et al. ${ }^{18}$. Stock ABTS. solution was prepared by reacting aqueous of ABTS. ( $7 \mathrm{mM}$ ) with potassium persulfate solution $(2.45 \mathrm{mM})$. The mixed solution was incubated for $12-16 \mathrm{~h}$ in the dark at room temperature. The absorbance of reaction mixtures was measured at $734 \mathrm{~nm}$. Three independent experiments were performed. An analogue of vitamin E, Trolox was used as the positive control ${ }^{19}$. The results were compared with Trolox and expressed as $\mathrm{IC}_{50}$ as follows:

$\%$ ABTS inhibition $=\left[\right.$ (Absorbance $_{\text {control }}$ - Absorbance test sample $) /$ Absorbance $\left.\left.{ }_{\text {control }}\right)\right] \times 100$

\section{LC-MS analysis}

For Liquid Chromatography Mass Spectroscopy (LC-MS) analysis $1 \mathrm{mg}$ methanol extract of $P$. spinosa fruit was dissolved in $5 \mathrm{~mL}$ ethanol and filtered through $0.22 \mu \mathrm{m}$ membrane filters. Methanol extract of $P$. spinosa fruit was analysed using LC-MS on a single quadrupole mass spectrometer (1200 LC, Agilent). For the chromatropic separation, LC-MS was run on an Agilent HPLC with an inner diameter (i.d.) of $4.6 \times 250 \mathrm{~mm}, 5 \mu \mathrm{m}$ particle size, octadecyl silica gel analytical $\mathrm{C} 18$ column and its temperature was maintained at $40^{\circ} \mathrm{C}$. The elution gradient consisted of mobile phases of A: Acetonitrile: Water: Formic acid (10:89:1, v/v/v) and B: Acetonitrile: Water: Formic acid (89:10:1, $\mathrm{v} / \mathrm{v} / \mathrm{v})$. The gradient elution established in the time frame of 0-40 min, B\% 15-100. The solvent flow rate was maintained at $0.7 \mathrm{~mL} / \mathrm{min}$. The injection volume was $20 \mu \mathrm{L}^{20}$.

\section{In vitro Cytotoxicity Assays}

\section{Cell Culture}

In this study, three different brain cancer cell lines and two different pancreas cancer cell lines were used. Glioblastoma brain cancer cell lines U87-GBM (ATCC, \#HTB-14), LN229-GBM (ATCC, \#CRL-2611), T98G-GBM (ATCC, \#CRL-1690), and pancreas cancer cell lines PANC-1 (ATCC, \#CRL1469), ASPC-1 (ATCC, \#CRL-1682) cell lines were purchased from ATCC (U.S.A.). Then the cells were grown and expanded in DMEM (Gibco) medium with $10 \%$ fetal bovine serum (Gibco), $1 \%$ antibiotics (penicillin/streptomycin) at $37^{\circ} \mathrm{C}$ in $5 \%$ $\mathrm{CO}_{2}$ incubator. The cells were then removed from the flask with Trypsin/EDTA $0.25 \%$ (Gibco) and seeded at a density of $5 \times 10^{3}$ cells/well into 96 black well plates (Corning) for cell viability assays that measures metabolically active cells.

\section{Cell Viability Assays}

Extracts were dissolved in methanol to prepare stock solutions, and serial dilutions were made using $1 \%$ methanol as a final concentration to normalize measurements. After seeding into 96 well plates, cells were incubated at $37^{\circ} \mathrm{C}$ in $5 \% \mathrm{CO}_{2}$ for 24 hours. Then the culture medium was discarded and cells were treated three times with 1,5,10,20 $\mathrm{mg} / \mathrm{ml}$ of methanol extracts of $P$. spinosa fruit. Af- 
ter 24 hours of treatment, Cell Titer Glo reagent (Promega) added into each well and the percentage of viable cells were determined by reading luminescence signals using SpectraMax i3x MultiMode Detection Platform.

\section{Statistical Analysis}

Statistical comparisons were performed by unpaired Student's t-test assuming equal variance. Data are descriptively represented as the mean \pm standard error (SE). Differences were considered as statistically significant at $\left(p^{*}<0.001\right.$ and $\left.\mathrm{p}^{* *}<0.0005\right)$.

\section{RESULTS}

\section{Total phenolic content}

The content of phenolic compounds in methanol extract of $P$. spinosa fruit was presented in Table 1.

Table 1. Total phenolic content of P. spinosa fruit methanol extract.

\begin{tabular}{ll}
\hline Plant extract & mg GA/100 g extract \pm SD \\
\hline $\begin{array}{l}\text { P. spinosa fruit } \\
\text { methanol extract }\end{array}$ & $2548 \pm 18$
\end{tabular}

\section{In vitro antioxidant assays}

The free radical scavenging activity of methanol extract of $P$. spinosa fruit was determined using ABTS and DPPH experiments and the outcomes are expressed in Table 2.

Table 2. ABTS and DPPH scavenging activities P. spinosa fruit methanol extract.

\begin{tabular}{lll}
\hline & $\begin{array}{l}\text { P. spinosa } \\
\text { IC50 } 5 \text { SD }(\mathbf{m g} / \mathbf{m l})\end{array}$ & References \\
\hline ABTS $^{1}$ & $0,1896 \pm 0,1143$ & $0,014 \pm 0,001$ (Trolox) \\
DPPH $^{2}$ & $0,0729 \pm 0,0348$ & $0,0154 \pm 0,002$ (BHT) \\
\hline
\end{tabular}

${ }^{1}$ ABTS: 2,2'-azino-bis 3-ethylbenzthiazoline-6-sulfonic acid ${ }^{2}$ DPHH: 2,2-diphenyl-1-picrylhydrazyl

\section{LC/MS Analysis}

The phytochemical constituent of the extract was analysed using LC-MS, which led to the identification of different compounds. The flavonoid com- ponent of methanol extract of $P$. spinosa fruit was characterized as quercetin (Figures 1 and 2).

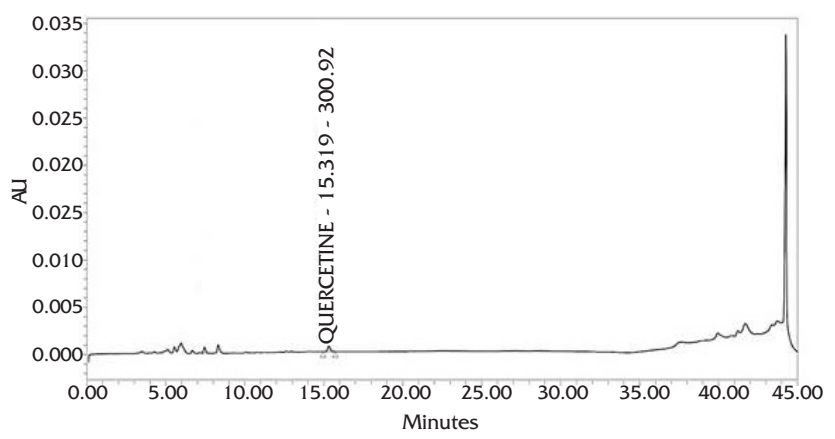

Figure 1. P. spinosa methanol extract LC-MS chromatogram.

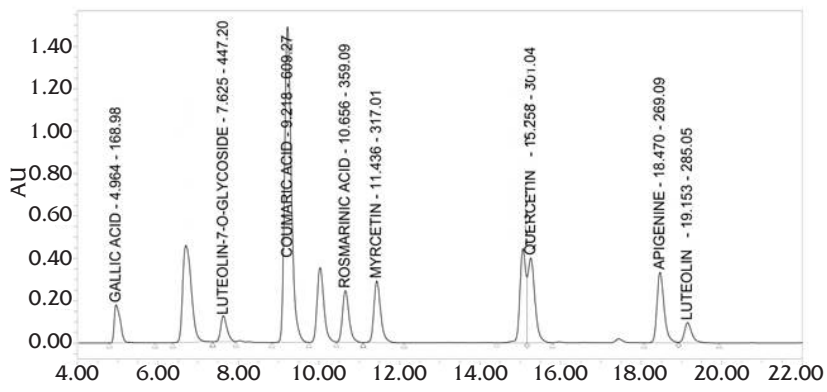

Figure 2. LC-MS standard chromatogram. Standards: 1, Gallic acid (R.T. 4,96); 2, Luteolin-7-o-glycoside (R.T. 7,62); 3, Coumaric acid (R.T. 9,21); 4, Rosmarinic acid (R.T. 10,65); 5, Myrcetin (R.T. 11,43); 6, Quercetin (R.T. 15,25); 7, Apigenine (R.T. 18,47); 8 Luteolin (R.T. 19,15) (R.T.=Retention time).

\section{In vitro Cytotoxicity Assays}

We analysed cytotoxicity of methanol extract of P. spinosa fruit on glioblastoma multiform (GBM) brain cancer (U87, LN229, T98G), and pancreas cancer (PANC-1, ASPC-1) cell lines. A luminescent based assay was used to measure metabolically active cells. According to our findings, among all lines treated with $P$. spinosa extract, only LN-229 cells showed significant decrease in viability at 10 $\mathrm{mg} / \mathrm{ml}$ concentration (Figure 3a). Additionally, GBM cell lines showed decreased cell viability at varying concentrations $(1 \mathrm{mg} / \mathrm{ml}, 5 \mathrm{mg} / \mathrm{ml}, 10$ $\mathrm{mg} / \mathrm{ml}$ and $20 \mathrm{mg} / \mathrm{ml}$ ). Especially when treated with $20 \mathrm{mg} / \mathrm{ml}$ extract, statistically significant $\left(\mathrm{P}^{* *}<0.0005\right)$ cell death was determined in all GBM cell lines. Treatment with $20 \mathrm{mg} / \mathrm{ml}$ extracts of $P$. spinosa resulted in 50\%, 54\% and $63 \%$ vi- 
a.

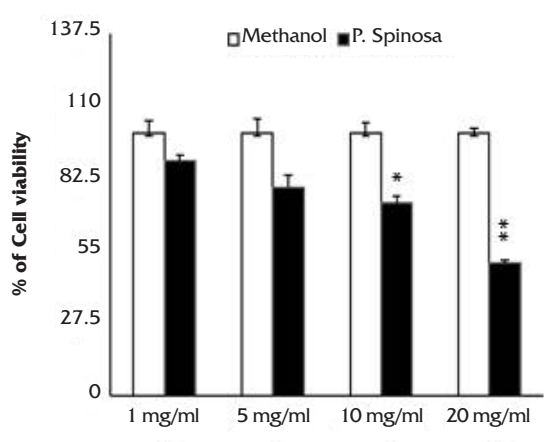

LN-229 GBM Cell Line

Normalize of dose vs. response

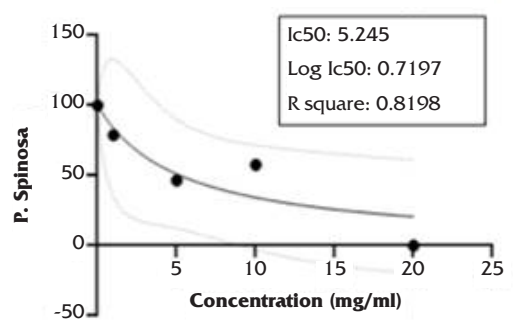

b.

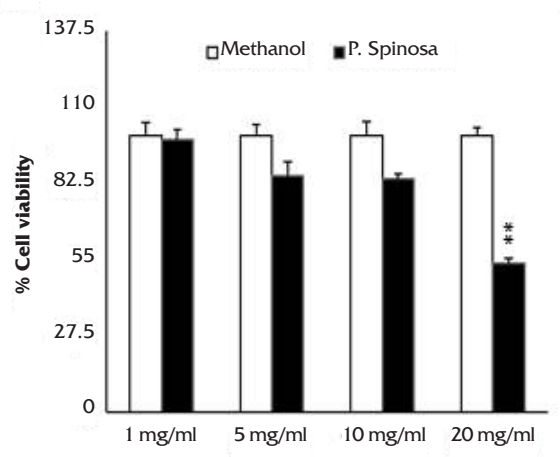

U-87 GBM Cell Line

Normalize of dose vs. response

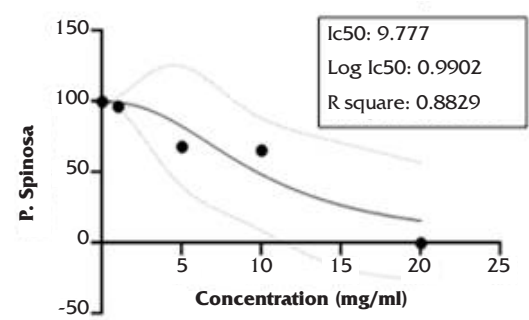

c.

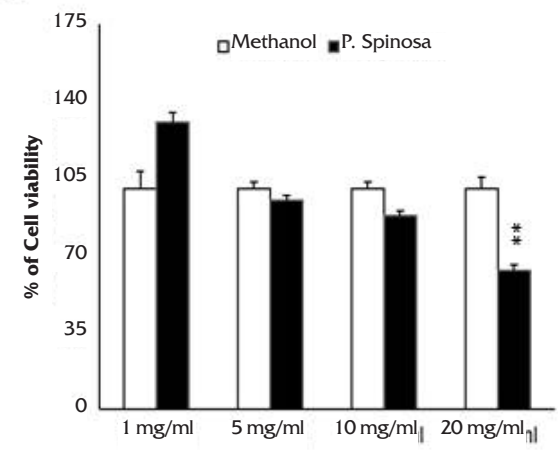

T98G GBM Cell Line

Normalize of dose vs. response

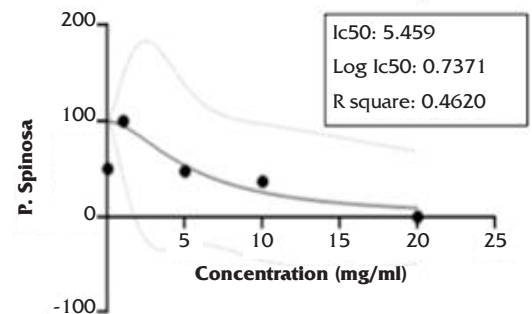

Figure 3. Cytotoxic effects of $\boldsymbol{P}$. spinosa fruit methanol extract on different glioma cell lines. Glioma cell lines were treated with $1-20 \mathrm{mg} / \mathrm{ml}$ P. spinosa fruit methanol extract for 24 hours and significantly decreased cell viability of $20 \mathrm{mg} / \mathrm{ml}$ treated a) LN229, b) U87 and c) U87 cell lines were recorded. Percentage of viable cells were determined as \%50, \%54 and $\% 63$ for $20 \mathrm{mg} / \mathrm{ml}$ treated LN229, U87 and T98G cell lines respectively when compared to the methanol (control) treatments only. Data are the mean \pm standard error (SE) and significance was determined as $\mathbf{p}^{*}<0.001$ and $\mathbf{p}^{* *}<0.0005$ when compared to control (methanol) treatments.

a.

Pancreas Cancer Cell Line

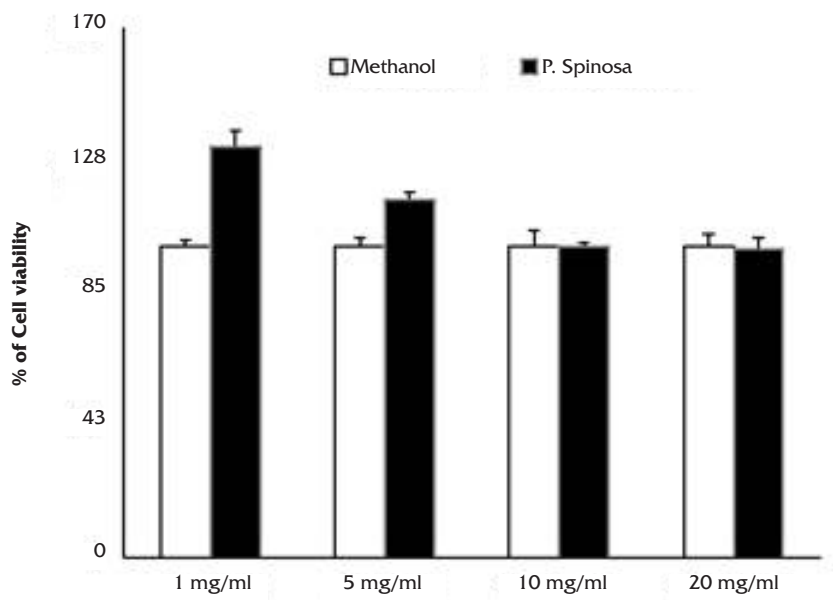

b.

AsPC- 1

Pancreas Cancer Cell Line

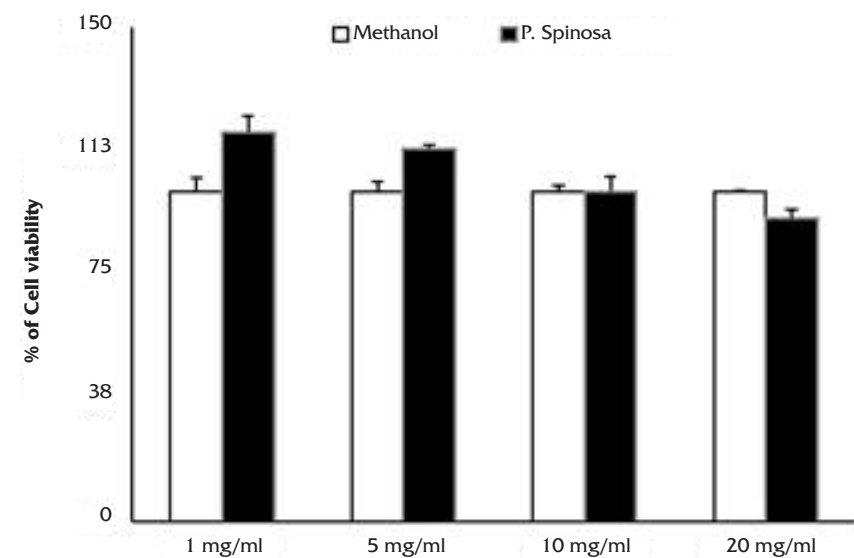

Figure 4. Cytotoxicity analysis of $P$. spinosa fruit methanol extract on pancreas cancer cell lines. Cell viability of a) PANC-1 and b) AsPC-1 cell lines were not affected by the treatment with $1-20 \mathrm{mg} / \mathrm{ml}$ concentrations of $P$. spinosa fruit methanol extract. Data are descriptively represented as the mean \pm standard error (SE). 
ability of LN229, U87 and T98G cells respectively. Accordingly, $5.245 \mathrm{mg} / \mathrm{ml} ; 9.777 \mathrm{mg} / \mathrm{ml}$ and $5.459 \mathrm{mg} / \mathrm{ml}$ of methanol extracts of $P$. spinosa fruit showed IC50 values for LN229; U87; and T98G GBM cell lines respectively (Figure 3a-c).

After evaluation of cytotoxic effects against brain cancer, we further investigated whether $P$. spinosa extract exerted comparable cytotoxic effects on other type of cancers. We then analysed the cell viability of two different pancreas cell lines treated with $P$. spinosa fruit methanol extract at the same concentrations (1-20 mg/ml). According to our results, cytotoxic effects of methanol extract of $P$. spinosa fruit in both pancreas cancer cell lines (ASPC-1 and PANC-1) tested could not be revealed (Figure 4$)$.

To sum up, although several phenolic and flavonoid standards were performed in the LC-MS study, a bioflavonoid, Quercetin (3,3',4'5,7-Pentahydroxyflavone) was detected in the $P$. spinosa fruit extract. In addition to that, we observed significant in vitro cytotoxic effects of $10-20 \mathrm{mg} / \mathrm{ml}$ methanol extracts of $P$. spinosa fruit in 3 different GBM brain cancer cell lines with different $\mathrm{IC}_{50}$ values.

\section{DISCUSSION}

In current medical practice, use traditional and alternative therapeutic approaches against cancer is a phenomenon under investigation. Namely, these studies require first set of in vitro experiments including antioxidant and cytotoxic activities of several plant extracts. $P$. spinosa is reported as one of the traditionally used and promising plant based therapeutics for several health problems involving hypertension, diabetes and gastrointestinal disorders. However, cytotoxicity of $P$. spinosa extracts against cancer cells were poorly studied. Accordingly, in this study, we evaluated potential antioxidant activities and in vitro cytotoxic effects of $P$. spinosa fruit extract in different cell lines of brain and pancreas cancers.
Extraction is an important step in the itinerary of phytochemical processing for the discovery of bioactive constituents from plant materials. Selection of a suitable extraction technique is also important for the standardization of herbal products as it is utilized in the removal of desirable soluble constituents, leaving out those not required with the aid of the solvents. Further, selection of suitable extraction process and optimization of various parameters are critical for upscaling purposes i.e. from bench scale to pilot plant level ${ }^{21}$. The selection of solvent system largely depends on the specific nature of the bioactive compound being targeted. Different solvent systems are available to extract the bioactive compound from natural products. The extraction of hydrophilic compounds uses polar solvents such as methanol, ethanol or ethyl-acetate ${ }^{22}$. In this study methanol was used for extraction because of total amount of flavonoids and phenolic compounds were found to be higher in methanol extract ${ }^{23}$.

Today, application of phenolic substances takes an important place in essential industries such as food, health, pharmaceutical and cosmetic. These substances are common in the phyto world as part of human diet and are attractive as natural antioxidants $^{24}$. Oxidative stress is one of the major pathological mechanisms and has a key role in formation of many diseases such as diabetes and cancer. Antioxidant phenolic compounds at least possess one aromatic ring including hydroxyl group(s) and antioxidant capacity of these compounds is mostly owing to their tendency to chelate metals by the referred groups ${ }^{25}$. In this study, the antioxidant activity of the $P$. spinosa extract has been shown. Moreover, by LC-MC analysis, several active compounds were identified from the extract.

Nonetheless, occasionally it is hard to find a connection between phenolic compounds, and their anticancer and antioxidant activities, suggesting the need of more detailed studies on the anticancer and antioxidant activities of isolated phenolic compounds ${ }^{25}$. 
Quercetin is one of the beneficial flavonoids with significant bioactivities like antidiabetic, angiogenesis inhibitory, cell cycle modulating, antioxidant, apoptosis-inducing, anti-inflammatory activities.

Numerous in vitro studies have shown anticancer activities of quercetin in a variety of cancer cells such as MDA-MB-453 (breast cancer); U2.US/ MTX300 (osteosarcoma); HeLa (cervical cancer); U138MG (glioma); HT-29 (colorectal xenografts); CWR22Rv1 (prostate cancer) and also quercetin can block increase and spread of melanoma, and inhibit its metastatic potential ${ }^{26}$. Quercetin exerts anticancer activities by inhibiting G1/S or G2/M phases of cell cycle and main cellular targets of qurcetin are topoisomerase II, p27, p21, and cyclin B. Moreover, free radical scavenging activity of quercetin can reduce cancer by recognizing three reactive centres ${ }^{27}$.

A prior study which was conducted with different plant extracts revealed that $P$. spinosa extract naturally enriched with non-anthocyanin phenolic compounds demonstrated the strongest antitumor activity against several human tumour cells (cervical, hepatocellular, colon, breast, and lung carcinomas) ${ }^{14}$.

First of all, we made a set of experiments on a healthy control cell line (human primary fibroblasts (HDFa), ATCC \#PCS-201-012) to determine the working concentrations for cytotoxicity experiments. Then, we optimized a dose range (1-20 $\mathrm{mg} / \mathrm{ml}$ ) which is cytotoxic for cancer cells without any harmful effect in healthy control cells. For this reason we did not use higher doses of extract which is cytotoxic to any cells without cancer selectivity. According to our in vitro cellular toxicity experiments, when treated with $20 \mathrm{mg} / \mathrm{ml}$ methanol extract of $P$. spinosa fruit we observed \%50; $\% 54$; and \%63 significant decrease in viability of LN-229, U-87 and T98G GBM brain cancer cell lines respectively. Since $P$. spinosa is traditionally used for gastrointestinal disorders, we then tested toxic effects of the extract against pancreas cancer. Interestingly, pancreatic cancer cell lines maintained their viability even at the highest dose of $20 \mathrm{mg} / \mathrm{ml}$ while under the same experimental conditions GBM brain cancer cell lines showed significant cellular toxicity. These findings indicate that $P$. spinosa fruit extract has cytotoxic effects on GBM brain cancer cell lines (LN-229, U-87 and T98G) whilst no effects on pancreatic cancer cells.

\section{CONCLUSION}

Depending on the cancer types (even the heterogenic cancer cell populations in the same tumour niche) and their underlying pathology, cytotoxic effects of therapeutics can vary remarkably. In line with this, the results of this study also revealed that $P$. spinosa fruit extract acts as a tissue-specific manner and it is selectively cytotoxic to GBM brain cancer cells rather than pancreatic cancers. Further in vitro investigations on anti-cancer effects of several $P$. spinosa extracts in brain cancers and determination of mechanisms that lead to its selective toxicity in GBM cell lines may induce new therapeutic inventions against brain cancers.

\section{REFERENCES}

1. Ayla Ş, Günal MY, Sayın Şakul AA, et al. Effects of Prunus spinosa L. fruits on experimental wound healing. Medeniyet Med J. 2017;32:152-8. [CrossRef]

2. Ruiz-Rodríguez BM, de Ancos B, Sánchez-Moreno C, et al. Wild blackthorn (Prunus spinosa L.) and hawthorn ( Crataegus monogyna Jacq.) fruits as valuable sources of antioxidants. Fruits. 2014;69:61-73. [CrossRef]

3. Baytop T. Türkiye'de bitkiler ile tedavi 2. Nobel Tıp Kitabevleri, İstanbul, 1999; 204-5.

4. Davis PH. Flora of Turkey and the East Aegean Islands. Vol.4. Edinburgh University Press, Edinburgh UK, 1982; 153.

5. Çalışır S, Haciseferogullari H, Özcan M, Arslan D. Some nutritional and technological properties of wild plum (Prunus spp.) fruits in Turkey. J Food Eng. 2005;66:233-7. [CrossRef]

6. Olszewska $M$, Wolbis $M$. Flavonoids from the flowers of Prunus spinosa L. Acta Pol Pharm. 2001;58(5):367-72.

7. Kültür Ş. An ethnobotanical study of Kırklareli (Turkey). Phytol Balcan. 2008;14:279-89.

8. Mustafa B, Hajdari A, Pajazita Q, Syla P, Quave CL, Pieroni A. An ethnobotanical survey of the Gollak region, Kosovo. Genet Resour Crop Evol. 2012;59(5):739-54. [CrossRef] 
9. Velickovic JM, Kostic DA, Stojanovic GS, et al. Phenolic composition, antioxidant and antimicrobial activity of the extracts from Prunus spinosa L. fruit. Hem Ind. 2014;68(3):297-303. [CrossRef]

10. Sikora E, Bieniek MI, Borczak B. Compositıon and antioxidant properties of fresh and frozen stored blackthorn fruits (Prunus spinosa L.). Acta Sci Pol Technol Aliment 2013;12(4):365-72. http://www.food.actapol.net/issue4/volume/3_4_2013.pdf.

11. Fraternale D, Giamperi L, Bucchini A, Sestili P, Paolillo M, Ricci D. Prunus spinosa fresh fruit juice: antioxidant activity in cell-free and cellular systems. Nat Prod Commun. 2009;4:1665-70. [CrossRef]

12. Irizar AC, Fernandez MF, González AG, Ravelo AG. Constituents of Prunus spinosa. J Nat Prod 1992;55:450-4. [CrossRef]

13. Egea I, Sánchez-Bel P, Romojaro F, Pretel MT. Six edible wild fruits as potential antioxidant additives or nutritional supplements. Plant Foods Hum Nutr. 2010;65:121-9. [CrossRef]

14. Guimarães R, Barros L, Calhelha RC, Carvalho AM, Queiroz MJ, Ferreira IC. Bioactivity of different enriched phenolic extracts of wild fruits from Northeastern Portugal: a comparative study. Plant Foods Hum Nutr. 2014;69:37-42. [CrossRef]

15. Okur ME, Ayla Ş, Çiçek Polat D, Günal MY, Yoltaş A, Biçeroğlu Ö. Novel insight into wound healing properties of methanol extract of Capparis ovata Desf. var. palaestina Zohary fruits. J Pharm Pharmacol. 2018;70:1401-13. [CrossRef]

16. Spanos GA, Wrolstad RE. Influence of processing and storage on the phenolic composition of Thompson Seedless grape juice. J Agric Food Chem. 1990;38:1565-71. [CrossRef]

17. Blois MS. Antioxidant determinations by the use of a stable free radical. Nature. 1958;181:1199-200. [CrossRef]

18. Re R, Pellegrini N, Proteggente A, Pannala A, Yang M, Rice-Evans C. Antioxidant activity applying an improved
ABTS radical cation decolorization assay. Free Radic Biol Med. 1999;26:1231-7. [CrossRef]

19. Okur ME, Polat DC, Ozbek H, Yılmaz S, Yoltaş A, Arslan R. Evaluation of the antidiabetic property of Capparis ovata Paleastina Zoh. Extracts using in vivo and in vitro approaches. Endoc Metab Immune Disord - Drug Tar. 2018;18:489-501. [CrossRef]

20. Gulsoy-Toplan G, Goger F, Yildiz-Peko A, Gibbons S, Sariyar G, Mat A. Chemical constituents of the different parts of Colchicum micranthum and $\mathrm{C}$. chalcedonicum and their Cytotoxic Activities. Nat Prod Commun. 2018;13:535-8. [CrossRef]

21. Dhanani T, Shah S, Gajbhiye NA, Kumar S. Effect of extraction methods on yield, phytochemical constituents and antioxidant activity of Withania somnifera. Arab J Chem. 2017;10:1193-9. [CrossRef]

22. Cos P, Vlietinck AJ, Berghe DV, Maes L. Anti-infective potential of natural products: how to develop a stronger in vitro 'proof-of-concept'. J Ethnopharmacol. 2006;106:290-302. [CrossRef]

23. Guimarães R, Barros L, Calhelha RC, Carvalho AM, Queiroz MJ, Ferreira IC. Bioactivity of different enriched phenolic extracts of wild fruits from Northeastern Portugal: a comparative study. Plant Foods Hum Nutr. 2014;69:37-42. [CrossRef]

24. Shahat AA, Hidayathulla S, Khan AA, et al. Phytochemical profiling, antioxidant and anticancer activities of Gastrocotyle hispida growing in Saudi Arabia. Acta Trop. 2019;191:243-7. [CrossRef]

25. Roleira FM, Tavares-da-Silva EJ, Varela CL, et al. Plant derived and dietary phenolic antioxidants: anticancer properties. Food Chem. 2015;183:235-58. [CrossRef]

26. Dajas F. Life or death: neuroprotective and anticancer effects of quercetin. J Ethnopharmacol. 2012;143:383-96. [CrossRef]

27. Men K, Duan X, Wei XW, et al. Nanoparticle-delivered quercetin for cancer therapy. Anticancer Agents Med Chem. 2014;14:826-32. [CrossRef] 